2014

\title{
Law, Culture and Visual Studies
}

Richard K. Sherwin

New York Law School

Follow this and additional works at: http://digitalcommons.nyls.edu/fac_books

Part of the Arts and Humanities Commons, and the Law Commons

\section{Recommended Citation}

Sherwin, Richard K., "Law, Culture and Visual Studies" (2014). Books. 26.

http://digitalcommons.nyls.edu/fac_books/26

This Book is brought to you for free and open access by the Faculty Scholarship at DigitalCommons@NYLS. It has been accepted for inclusion in Books by an authorized administrator of DigitalCommons@NYLS. 
Anne Wagner

Richard K. Sherwin Editors

Law, Culture

and Visual Studies

Springer 
Anne Wagner - Richard K. Sherwin Editors

\section{Law, Culture and Visual Studies}

基 Springer 
Anne Wagner

Centre de Recherche Droits et Perspectives

du Droit, équipe René Demogue

Université Lille - Nord de France

Lille, France
Richard K. Sherwin

New York Law School

New York, USA

ISBN 978-90-481-9321-9

DOI 10.1007/978-90-481-9322-6

ISBN 978-90-481-9322-6 (eBook)

Springer Dordrecht Heidelberg New York London

Library of Congress Control Number: 2013936986

(1) Springer Science+Business Media Dordrecht 2014

This work is subject to copyright. All rights are reserved by the Publisher, whether the whole or part of the material is concerned, specifically the rights of translation, reprinting, reuse of illustrations, recitation, broadcasting, reproduction on microfilms or in any other physical way, and transmission or information storage and retrieval, electronic adaptation, computer software, or by similar or dissimilar methodology now known or hereafter developed. Exempted from this legal reservation are brief excerpts in connection with reviews or scholarly analysis or material supptied specifically for the purpose of being entered and executed on a computer system, for exclusive use by the purchaser of the work. Duplication of this publication or parts thereof is permitted only under the provisions of the Copyright Law of the Publisher's location, in its current version, and permission for use must always be obtained from Springer. Permissions for use may be obtained through RightsLink at the Copyright Clearance Center. Violations are liable to prosecution under the respective Copyright Law.

The use of general descriptive names, registered names, trademarks, service marks, etc. in this publication does not imply, even in the absence of a specific statement, that such names are exempt from the relevant protective laws and regulations and therefore free for general use.

While the advice and information in this book are believed to be true and accurate at the date of publication, neither the authors nor the editors nor the publisher can accept any legal responsibility for any errors or omissions that may be made. The publisher makes no warranty, express or implied, with respect to the material contained herein.

Printed on acid-free paper

Springer is part of Springer Science+Business Media (www.springer.com) 


\section{Advance Praise for Law, Culture, and Visual Studies}

This diverse and exhilarating collection of essays explores the many facets both historical and contemporary of visual culture in the law. It opens a window onto the substantive, jurisdictional, disciplinary, and methodological diversity of current research. It is a cornucopia of materials that will enliven legal studies for those new to the field as well as for established scholars. It is a "must read" that will leave you wondering about the validity of the long-held obsession that reduces the law and legal studies to little more than a preoccupation with the word.

Leslie J. Moran, Professor of Law, Birkbeck College, University of London

Law, Culture and Visual Studies is a treasure trove of insights on the entwined roles of legality and visuality. From multiple interdisciplinary perspectives by scholars from around the world, these pieces reflect the fullness and complexities of our visual encounters with law and culture. From pictures to places to postage stamps, from forensics to film to folklore, this anthology is an exciting journey through the fertile field of law and visual culture as well as a testament that the field has come of age.

Naomi Mezey, Professor of Law, Georgetown University Law Center, Washington, DC, USA

This highly interdisciplinary reference work brings together diverse fields including cultural studies, communication theory, rhetoric, law and film studies, legal and social history, and visual and legal theory, in order to document the various historical, cultural, representational, and theoretical links that bind together law and the visual. This book offers a breathtaking range of resources from both well-established and newer scholars who together cover the field of law's representation in, interrogation of, and dialogue with forms of visual rhetoric, practice, and discourse. Taken together, this scholarship presents state-of-the-art research into an important and developing dimension of contemporary legal and cultural inquiry. Above all, Law Culture and Visual Studies lays the groundwork for rethinking the nature of law in our densely visual culture: How are legal meanings produced, encoded, distributed, 
and decoded? What critical and hermeneutic skills, new or old, familiar or unfamiliar, will be needed? Topical, diverse, and enlivening, Law Culture and Visual Studies is a vital research tool and an urgent invitation to further critical thinking in the areas so well laid out in this collection.

Desmond Manderson, Future Fellow, ANU College of Law/Research School of Humanities and the Arts, Australian National University, Australia 


\section{Contents}

Introduction: Law, Culture, and Visual Studies

Richard K. Sherwin

\section{Part I Introducing Visual Legal Studies}

1 Devising Law: On the Philosophy of Legal Emblems Peter Goodrich

2 Law and Image: Towards a Theory of Nomograms Paolo Heritier

3 The Book as Authoritative Sign in Seventeenth-Century England: A Review Through the Lens of Holistic Media Theory

Paul Douglas Callister

4 Representing Sovereignty in Renaissance England: Pictorial Metaphors and the Visibility of Law ....

Cristina Costantini and Lucia Morra

5 Visual Common Sense

Neal Feigenson

6 The Photographic Image: Truth or Sign? Ira Torresi

7 Visualization Between Fictitious Law and Factual Behaviour:

A Pragmatic-Institutional Analysis Hanneke van Schooten

\section{Part II Visualizing Legal Scholarship}

8 The First Amendment and the Second Commandment Amy Adler 
9 The Semiotics of Film in US Supreme Court Cases

Jessica Silbey and Meghan Hayes Slack

10 Looking Again at Photographs and Privacy: Theoretical

Perspectives on Law's Treatment of Photographs

as Invasions of Privacy

David Rolph

11 Drawing Attention: Art, Pornography, Ethnosemiotics and Law

Alec McHoul and Tracey Summerfield

12 What's Wrong with Pink Pearls and Cornrow Braids?

Employee Dress Codes and the Semiotic Performance

of Race and Gender in the Workplace

Janet Ainsworth

13 Semiotic Interpretation in Trademark Law: The Empirical

Study of Commercial Meanings in American English of $\{$ Rn

Ronald R. Butters

14 A Multimodal Social Semiotic Approach to Shape

in the Forensic Analysis of Trademarks

Christian Mosbæk Johannessen

15 French Commemorative Postage Stamps as a Means

of Legal Culture and Memory

Anne Wagner and Malik Bozzo-Rey

16 The Criminal Trial as Theater: The Semiotic

Power of the Image

Denis J. Brion

Part III Law and Iconic Art

17 Do You See What I See? Iconic Art and Culture

and the Judicial Eye in Australian Law

Marett Leiboff

18 The Iconography of the Giving of the Law:

A Semiotic Overview

Massimo Leone

19 Daumier and Replacing the King's Body

Oliver Watts

20 Law, Code, and Governance in Prophetic Painting:

Notes on the Emergence of Early, High, and Late

Modern Forms of Life and Governance

Ronnie Lippens 
Part IV Visualizing Law in Indigenous or Folk Loric Culture

21 Signs at Odds? The Semiotics of Law, Legitimacy, and Authenticity in Tribal Contexts

Renee Ann Cramer

22 Emblem of Folk Legality: Semiotic Prosecution

and the American Bald Eagle.

Sarah Marusek

Part V Visualizing Law's Topography

23 Constructing Courts: Architecture, the Ideology of Judging, and the Public Sphere.

Judith Resnik, Dennis Curtis, and Allison Tait

24 Saying the Saffu and Beating the Law: The Changing

Role of Sacred Sites in the Oromo Politico-Juridical System

Pekka Virtanen

25 The Mandala State in Pre-British Sri Lanka:

The Cosmographical Terrain of Contested Sovereignty

in the Theravada Buddhism Tradition

Roshan de Silva Wijeyeratne

26 Linguistic Landscape, Law and Reflexive Modernity

Christopher Mark Hutton

27 Visual Art in American Courthouses

James R. Fox

Part VI Visual Technologies of Law

28 Mediating Disputes with Digital Media

Maurizio Gotti and Larissa D'Angelo

29 The Alleged Liveness of "Live": Legal Visuality, Biometric

Liveness Testing and the Metaphysics of Presence

Joseph Pugliese

30 Visual Legal Commentary

Karen Petroski

31 The Invisible Court: The Foreign Intelligence Surveillance

Court and Its Depiction on Government Websites

Pamela Hobbs 
Part VII Law and Popular Visual Media: "Case Studies"

32 Seeking Truth and Telling Stories in Cinema and the Courtroom:

Reversal of Fortune's Reflexive Critique.

Cynthia Lucia

33 Hollywood's Hero-Lawyer: A Liminal Character

and Champion of Equal Liberty.

Orit Kamir

34 The Representation of Law on Film: Mr. Deeds

and Adam's Rib Go to Court

Wim Staat

35 Justice for the Disabled: Crime Films on Punishment

and the Human Rights of People with Learning Disabilities

Majid Yar and Nicole Rafter

36 'Make Enough Money, Everything Else Will Follow':

Litigation and the Signification of Happiness

in Popular Culture

Jason Bainbridge

37 Trial by Ordeal: CSI and the Rule of Law

Christina O. Spiesel

38 The Visibly Offensive Offender: A Semiotic Phenomenotogy of an Execution

Jody Lynée Madeira

39 A Tale of Many Newspapers: Perversion, Criminality, and Scopophilia in the Edison Chen Scandal

Marco Wan and Janny Leung

Part VIII Law and Popular Visual Media: In Theory

40 Make 'em Laugh: Images of Law in Eighteenth Century

Popular Culture.

Mary Hemmings

41 Judge Dredd: Dreaming of Instant Justice

Alexander V. Kozin

42 Oil and Water Do Not Mix: Constitutional Law and American Popular Culture

David Ray Papke

43 Where There Is No Need to Screen Local Justice:

Law and Film in Israel

Shulamit Almog 
44 Influence of Public Perceptions of Media Legality on Making Biopic Films. Betty L. Hart

45 Film and the Reconstruction of Memory.

Farid Samir Benavides Vanegas

46 The Impact of Film and Television on Perceptions of Law and Justice: Towards a Realisable Methodology. 1011 Peter Robson, Guy Osborn, and Steve Greenfield 


\section{Biographical Notes on the Editors}

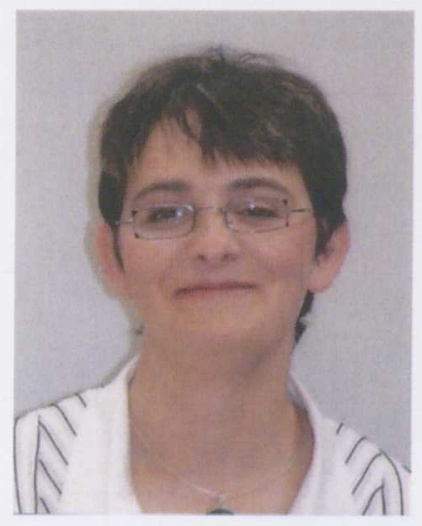

Anne Wagner is an Associate Professor at the Université Lille - Nord de France. She is a research member at the Université Lille - Nord de France (Centre de Recherche Droits et Perspectives du Droit, équipe René Demogue: http://crdp.univlille2.fr/le-centre/). She is a Research and Adjunct Professor at China University of Political Science and Law (Beijing). She is a permanent member of the Instituto Subalpino per l'Analisi e l'Insegnamento del Diritto della Attivita Transanzionali (ISAIDAT with Prof. Rodolfo Sacco). She is the Editor in Chief of the International Journal for the Semiotics of Law (http://www.springer.com/law/journal/11196 Springer) and the Series Editor of Law, Language and Communication (http://www. ashgate.com/default.aspx ?page $=3916$ - Ashgate). She is President of the International Roundtables for the Semiotics of Law and Vice President of the Multicultural Association of Law and Language (Hong Kong).

She has lectured in Asia, Australia, Europe, and North America. She has extensively published research papers in the area of law and semiotics, law and criminology, legal discourse analyses, law and culture, and legal translation. She is the Editor of Images in Law (2006, Ashgate); Legal Language and the Search for Clarity 
(2006, Peter Lang); Interpretation, Law and the Construction of Meaning (2006, Springer); Obscurity and Clarity in the Law (2008. Ashgate); Diversity and Tolerance in Socio-Legal Context (2009, Ashgate); Prospects of Legal Semiotics (2010, Springer); and Exploring Courtroom Discourse (2011, Ashgate). She is the author of La Langue de la Common Law (2002, L'Harmattan). She also has many editorial appointments as Guest Editor for Meta - Journal des traducteurs (2013) and Semiotica (2013).

In 2009, Anne Wagner began investigating Visual Studies with a close connection to visual semiotics and the way empty spaces, shapes, and garments can either subjugate or disrupt the public sphere and lead to disobedience, incivilities, and crimes: Nation, Identity and Multiculturalism (Guest Editor - International Journal for the Semiotics of Law, vol.25/2: 2012); French Urban Space Management - A Visual Semiotic Approach behind Power and Control (A. Wagner, International Journal for the Semiotics of Law, vol.24/2, 2011); and The Muslim Veil in France: Between Power and Silence, between Visibility and Invisibility (Hermes 46, 2011).
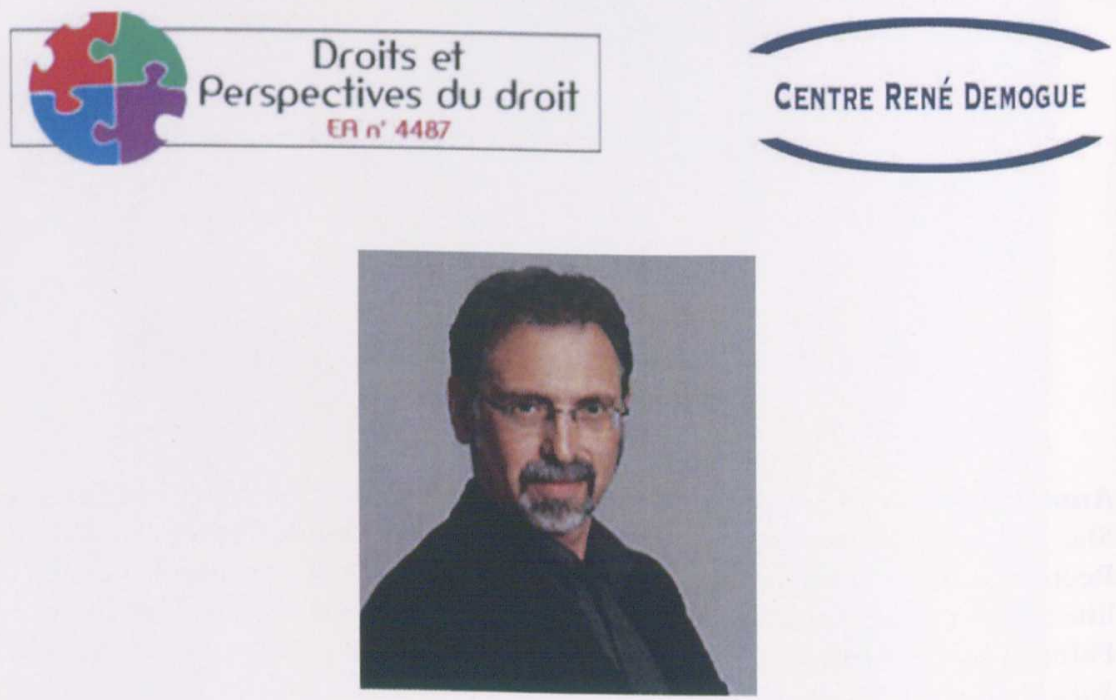

Richard K. Sherwin is Professor of Law and Director of the Visual Persuasion Project at New York Law School. He is the author of Visualizing Law in the Age of the Digital Baroque: Arabesques \& Entanglements (Routledge: 2011) and When Law Goes Pop: The Vanishing Line between Law and Popular Culture (University of Chicago Press: 2000 [2002]). He has written numerous chapters and articles on topics ranging from the interrelationship between law and culture, law and rhetoric, discourse theory, political legitimacy, and the emerging field of visual legal studies. Recent publications include "Law's Life on the Screen," in Sara Steinert-Borella and Caroline Wiedmer, eds., Intersections of Law and Culture (Palgrave Macmillan: 2012); "Constitutional Purgatory: Shades and Presences Inside the Courtroom," in 
Leif Dahlberg, ed., Visualizing Law and Authority (Walter de Gruyter: 2012); "Visual Jurisprudence," in the New York Law School Law Review Symposium Issue on "Visualizing Law in the Digital Age" (Fall 2012); "Law's Screen Life," in A. Sarat, ed., Imagining Legality (Alabama: 2011); and "Imagining Law as Film: Representation without Reference?" in Austin Sarat, et. al., Introduction to Law and the Humanities, (Cambridge University Press: 2010). He edited and also contributed to Popular Culture and Law (Ashgate: 2006).

In 2001, Professor Sherwin debuted Visual Persuasion in the Law, the first course of its kind to teach law students about the role and efficacy (as well as the pitfalls) of using visual evidence and visual advocacy in contemporary legal practice. Student films are produced in New York Law School's digital media lab.

In 2005, Professor Sherwin launched the Visual Persuasion Project (http://www. nyls.edu/centers/projects/visual_persuasion). The project seeks to promote a better understanding of the practice, theory, and teaching of law through the cultivation of critical visual intelligence. The web site showcases "best practices" in visual persuasion inside the courtroom through a broad range of visual products, from 2-D and 3-D animations to accident reenactments, day-in-the-life documentaries, settlement brochures, montages, and other innovative visual products.

A frequent public speaker both in the United States and abroad, Professor Sherwin is a regular commentator for television, radio, and print media on the relationship between law, culture, film, and digital media. His appearances include NBC's Today Show, WNET, National Public Radio, RTE Radio 1 (National Public Radio in Ireland), and CKUT (Montreal, Canada). 